\title{
Sm-Nd ages of two meta-anorthosite complexes around Holenarsipur: Constraints on the antiquity of Archean supracrustal rocks of the Dharwar craton
}

\author{
Y J Bhaskar RaO ${ }^{1}$, Anil Kumar ${ }^{1}$, A B VRevsky ${ }^{2}$, R Srinivasan ${ }^{1}$ and G V Anantha IyeR ${ }^{3}$ \\ ${ }^{1}$ National Geophysical Research Institute, Hyderabad 50000\%, India; email: postmast@csngri.ren.nic.in \\ ${ }^{2}$ Institute of Precambrian Geology and Geochronology, St. Petersburg, Russia. \\ ${ }^{3}$ Department of Inorganic and Physical Chemistry, Indian Institute of Sciences, Bangalore 560 012, India
}

\begin{abstract}
Whole-rock Sm-Nd isochron ages are reported for two stratiform meta-anorthosite complexes emplaced into the Archean supracrustal-gneiss association in the amphibolite facies terrain around Holenarsipur, in the Dharwar craton, South India. While these metaperidotite-pyroxenite-gabbro-anorthosite complexes are petrologically and geochemically similar, they differ in the intensity of tectonic fabric developed during the late Archean (c. $2.5 \mathrm{Ga}$ ) deformation. They also differ in their whole-rock Sm-Nd isochron ages and initial $\mathrm{Nd}$ isotopic compositions: $3.285 \pm 0.17 \mathrm{Ga}, \varepsilon_{\mathrm{Nd}}=0.82 \pm 0.78$ for the Honnavalli metaanorthosite complex from a supracrustal enclave in the low-strain zone, and $2.495 \pm 0.033 \mathrm{Ga}$, $\varepsilon_{\mathrm{Nd}}=-2.2 \pm 0.3$ for the Dodkadnur meta-anorthosites from the high-strain southern arm of the Holenarsipur Supracrustal Belt (HSB). We interpret these results as indicating that the magmatic protoliths of both meta-anorthosite complexes were derived from a marginally depleted mantle at $\mathrm{c}$. $3.29 \mathrm{Ga}$ but only the Dodkadnur rocks were isotopically reequilibrated on a cm-scale about $800 \mathrm{Ma}$ later presumably due to the development of strong penetrative fabrics in them during Late Archean thermotectonic event around $2.5 \mathrm{Ga}$. Our results set a younger age limit at c. $3.29 \mathrm{Ga}$ for the supracrustal rocks of the HSB in the Dharwar craton.
\end{abstract}

\section{Introduction}

A general consensus is that the Archean gneiss-supracrustal associations of the Dharwar craton, southern India constitute a polyphase assemblage that developed between $\sim 3.4$ and $2.5 \mathrm{Ga}$ ago (reviewed by Naqvi and Rogers 1987). However, aspects of spatial and temporal relationships between gneisses and supracrustals, and the antiquity of the supracrustal rocks remain ambiguous. The region encompassing the Holenarsipur Supracrustal Belt (HSB, figure 1) has long been recognised as one of the oldest crustal nucleii in the Dharwar craton based on the evidence for preservation of the $\leq 3.3 \mathrm{Ga}$ tonalitic orthogneisses (Beckinsale et al 1980, 1982; Bhaskar Rao et al 1991; Meen et al 1992; Naha et al 1993; Peucat et al 1993). Geological and geochronological studies have been inconclusive on the temporal relationship between the spatially associated gneissic and supracrustal rocks. While some authors (e.g. Naqvi 1981; Hussain and Naqvi 1983) proposed that supracrustal rocks pre-date the gneisses, several others (e.g. Ramakrishnan and Viswanatha 1981; Monrad 1983; Meen et al 1992) suggested that the gneisses were older. $\mathrm{U} / \mathrm{Pb}$ ages of detrital zircons from a quartzitemetapelite unit from the HSB indicate granitoid rocks as old as $\sim 3.6 \mathrm{Ga}$ in its provenance (Nutman et al 1992). Peucat et al (1995) reported a precise $\mathrm{U} / \mathrm{Pb}$ age of $3.298 \pm 0.007 \mathrm{Ga}$ for zircons in a metarhyolite in the upper part of the stratigraphic sequence in the HSB implying that the entire supracrustal succession in this belt could be at least as old as the oldest dated $(\sim 3.3 \mathrm{Ga})$ Gorur gneiss nearby. In a different and complementary approach to the age of the supracrustal

Keywords. Archean; anorthosite; Dharwar craton; Sm-Nd; Geochronology. 


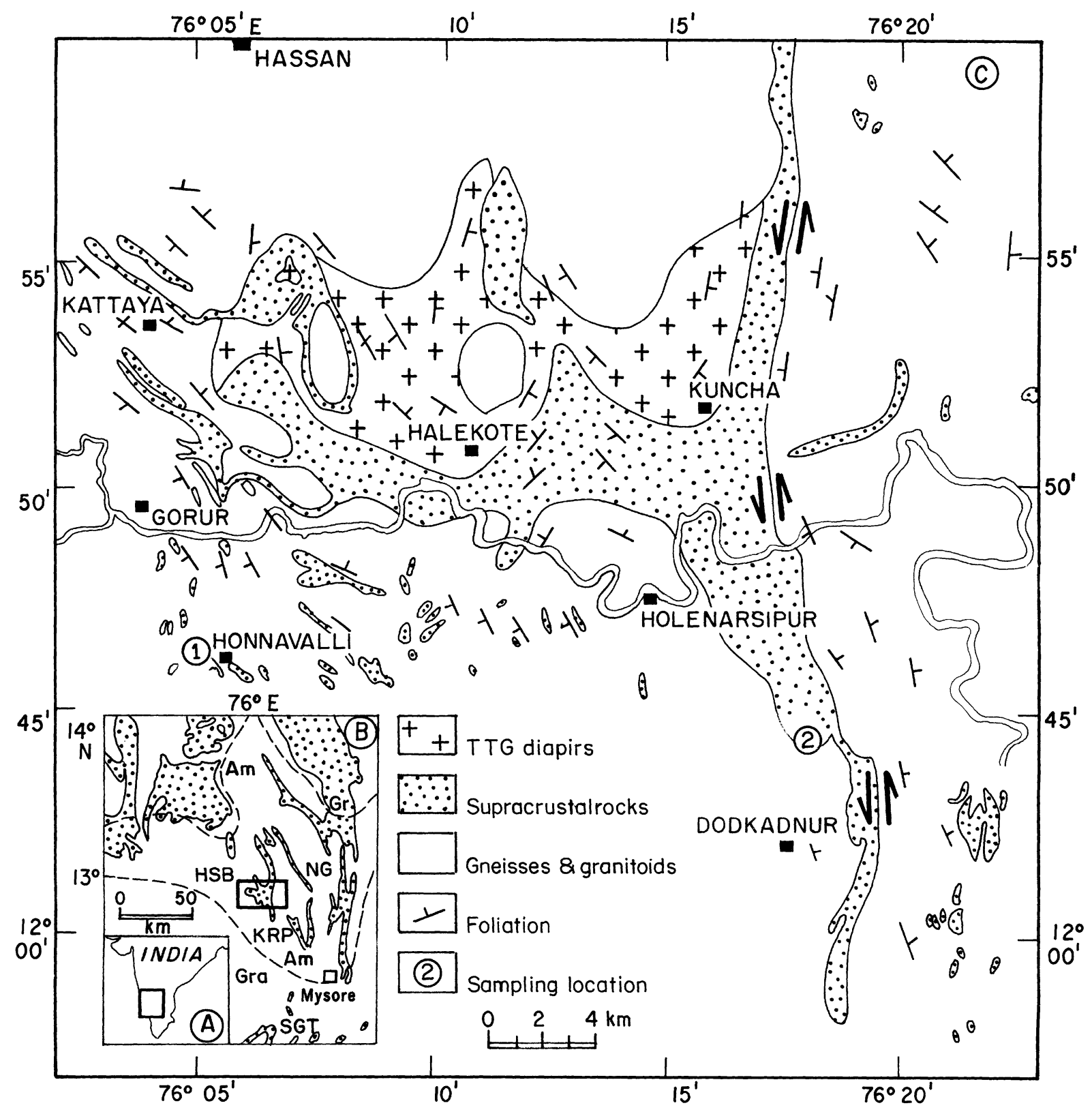

Figure 1. Generalised geological map of the Archean Holenarsipur Supracrustal Belt (HSB) and surrounding gneissic country showing location of the Honnavalli and Dodkadnur meta-anorthosite complexes (based on Hussain and Naqvi 1983). Inset - B shows the location of the HSB in the amphibolite (Am) - facies terrain of the western part of the Dharwar craton, south India which is bounded by greenschist facies (Gr) and Granulite (Gra) facies domains. Other supracrustal belts containing similar stratiform complexes include: Sargur (SG), Nuggihalli (NG) and Krishnarajpet (KRP).

sequence of the HSB, we have dated two isolated bodies of multiply deformed and metamorphosed stratiform periodite-gabbro-anorthosite suite from around Holenarsipur.

Many deformed stratiform dunite/periodite-pyroxenite-gabbro-anorthosite complexes are known from the lower sections of supracrustal belts such as the Holenarsipur, Nuggihalli, Sargur and Krishnarajpet in the western part of the Dharwar craton (WDC). Geology, petrology and geochemistry of these bodies have been described by Ramiengar et al (1978); Ramakrishnan et al (1978); Drury et al (1978); Naqvi and Hussain (1979); Ramakrishnan and Viswanatha (1981); Hussain and
Ahmad (1982); Kutty et al (1984) and have been reviewed recently by Nijagunappa (1994). Structurally these bodies are identical to their host supracrustal and/or gneiss rocks suggesting their emplacement before the regional deformation and metamorphic events. Relative to the metarhyolite dated by Peucat et al (1995), the stratiform suites considered here occupy a much lower stratigraphic position in the supracrustal succession around Holenarsipur. Therefore, the primary (crystallisation) age of these stratiform suites would set a strict younger (minimum) limit to the age of the supracrustal rocks of the HSB. 
A potential problem in using $\mathrm{Sm}-\mathrm{Nd}$ whole-rock isochron method to date deformed and metamorphosed mafic-ultramafic rock systems is the mobility of rare earth elements during secondary geological processes, particularly those involving exchange reactions between rocks and hydrothermal fluids. However, adoption of a proper sampling strategy considering the scale of tectonic fabrics developed in the rocks could help retrieve primary age information irrespective of their metamorphic grade (Black 1988). Many examples where whole rock Sm-Nd isochrons yielded reliable primary ages for stratiform anorthosite complexes in Archean greenstone belts elsewhere have been reviewed by Ashwal (1993).

\section{Geological setting}

In a tilted cratonic block exposing an oblique crosssection of Archean rocks ranging in metamorphic grade from greenschist facies in the north to granulite facies in the south, the Holenarsipur region forms a central medium-grade (amphibolite facies) domain. The trident shaped HSB has narrow northern, southern and western arms. The southern part of the western arm and the entire southern arm are believed by some workers to comprise the lower part of the supracrustal succession described variedly as the $>3.0 \mathrm{Ga}$ Sargur Group (Swami Nath et al 1976; Ramakrishnan and Viswanatha 1981), the oldest supracrustals (Naqvi 1981), and the Holenarsipur Group (Naqvi and Rogers 1987). This sequence is dominated by ultramafic schists of komatiite-tholeiite affinites, metapelites and minor quartzite, banded iron formation and numerous lensoid and/or sheet like bodies of stratiform duniteperiodite-pyroxenite gabbro-anorthosite. The northern part of the western arm and the northern arm contain a mafic metavolcanic-dominated sequence with rare spinifex textured komatiites. Minor felsic volcanic rocks occur in the upper stratigraphic level. The mafic volcanic rocks are interlayered with thin quartzite, argillite and a banded iron formation. This latter sequence was correlated with the $<3.0 \mathrm{Ga}$ Dharwar Supergroup, the younger Archean supracrustal cycle of the Dharwar craton (Swami Nath et al 1976; Ramakrishnan and Viswanatha 1981). This two-fold subdivision of the supracrustal sequence in the HSB has been refuted by other workers (Hussain and Naqvi 1983; Naha et al 1986, 1993; Srinivasan 1988; Srinivasan and Naha 1996).

Tonalitic orthogneisses west and northwest of the HSB have yielded whole rock $\mathrm{Rb}-\mathrm{Sr}, \mathrm{Pb}-\mathrm{Pb}$ and zircon $\mathrm{U} / \mathrm{Pb}$ ages between 3.350 and $3.305 \mathrm{Ga}$ (Beckinsale et al 1980, 1982; Monrad 1983; Taylor et al 1984; Bhaskar Rao et al 1991; Meen et al 1992; Naha et al 1993; Peucat et al 1993). The gneiss-supracrustal assemblage, including the stratiform complexes, is structurally concordant and bears evidence for two major and a minor episodes of deformation with metamorphism reaching up to amphibolite facies (Chadwick et al 1978, 1981; Naha et al 1986, 1993; Naqvi and Rogers 1987; Bhaskar Rao et al 1991). During the first episode ( $D_{1}$ and $\mathrm{D}_{1 \mathrm{a}}$ ) the rocks were isoclinally folded and co-axially refolded. An axial planar schistosity $\left(\mathrm{S}_{1}\right)$ was developed, and metamorphic conditions varied from greenschist facies in the north to amphibolite facies in the southern part of the HSB. Synkinematic tonalitetrondhjemite-granodiorite (TTG) diapirs invaded both the gneisses and supracrustal rocks. The distribution of $\mathrm{L}, \mathrm{L}-\mathrm{S}$ and $\mathrm{S}$ fabric dominated domains in the region is suggested to have been controlled by deformation associated with the rising TTG-diapirs (Bouhallier et al 1993, 1995). Several of these TTG suites have been dated at $\sim 3.0 \mathrm{Ga}$ (Beckinsale et al 1982; Monrad 1983; Stroh et al 1983; Taylor et al 1984). The c. 3.0 Ga event was also associated with migmatisation, remobilization of large ion lithophile elements and re-equilibration of $\mathrm{Rb}-\mathrm{Sr}$ and $\mathrm{Pb}-\mathrm{Pb}$ isotopic systematics in the gneisses (Bhaskar Rao et al 1983; Naqvi and Rogers 1987; Meen et al 1992). The $\mathrm{D}_{1}$-episode of deformation culminating at c. $3.0 \mathrm{Ga}$ is generally believed to mark a strict younger age limit to the deposition and early deformation and metamorphism of the Holenarsipur supracrustal rocks. During a second major episode of deformation $\left(\mathrm{D}_{2}\right)$, the earlier isoclinal folds and axial planar schistosity were refolded into N-S upright folds with $\mathrm{N}$-S striking axial planes. The $\mathrm{D}_{2}$-folding is associated with development of a zonal crenulation cleavage, marked by micas in the northern part and amphibole in the southern arm of the HSB. The $\mathrm{D}_{2}$-phase is also associated with strong transcurrent-shearing along N-S belts, such as the one along the eastern margin of the HSB that affected much of the southern arm (e.g. Drury et al 1984; Chadwick et al 1992; Bouhallier et al 1993, 1995). The N-S fabrics related to $\mathrm{D}_{2}$ are weak along much of the western arm of the HSB, where the pre- $\mathrm{D}_{2}$ structures and compositions are expected to be better preserved. Garnet-bearing amphibolites developed syntectonically with $\mathrm{D}_{2}$ give consistent whole rock-garnet $\mathrm{Sm}-\mathrm{Nd}$ isochron ages at $\sim 2.5 \mathrm{Ga}$ (Bouhallier 1995). In a regional context, the $\mathrm{D}_{2}$-episode coincides with a craton-wide late Archean tectonometamorphic event that culminated at c. $2.5 \mathrm{Ga}$ with charnockite formation at deeper levels and widespread emplacement of K-rich granites at the shallow crustal levels (reviewed by Naqvi and Rogers 1987; Friend and Nutman 1991; Peucat et al 1993). Locally around the HSB, late warps $\left(\mathrm{D}_{3}\right)$ with E-W axial planes accentuated the plunges of the $\mathrm{D}_{2}$-folds.

\section{The stratiform meta-anorthosite complexes}

The two bodies of deformed and metamorphosed stratiform peridotite-gabbro-anorthosite studied here are: 
- the Honnavalli meta-anorthosite, at the Honnavalli village approximately $20 \mathrm{~km}$ west of Holenarsipur and $3 \mathrm{~km}$ south of Gorur and

- the Dodkadnur meta-anorthosite, located $\sim 5 \mathrm{~km}$ south of Holenarsipur, $\sim 3.5 \mathrm{~km}$ north of Dodkadnur (figure 1).

The Honnavalli meta-anorthosite, first described by Hussain and Ahmad (1982), is a $(\sim 50 \times 20 \mathrm{~m})$ oval shaped body included in banded tonalitic gneisses and associated with actinolite-tremolite-talc-antigorite schists. The meta-anorthosite with $>90 \%$ modal plagioclase grades into gabbroic anorthosite with $80-90 \%$ modal plagioclase. The rock is coarse to medium-grained with a feeble foliation defined by a crude alignment of clots rich in hornblende. The foliation strikes NNW and dips $\sim 60-65^{\circ}$ easterly which is parallel to foliation in the enclosing gneisses (also see Hussain and Ahmed 1982; Hussain and Naqvi 1983). Plagioclase $\left(\mathrm{An}_{92}\right)$ in the anorthositic rock is variably sassuritised. The anorthosites are conformably associated with a thin $(20 \times 2 \mathrm{~m})$ band of schistose amphibolite containing largely hornblende and subordinate plagioclase $\left(\mathrm{An}_{70-85}\right)$. These can be interpreted as metagabbro ( $<30 \%$, modal plagioclase) and anorthositic gabbro (70-80\% plagioclase), zoisite, calcite, scapolite, titanomagnetite and chlorite are accessory minerals.

The Dodkadnur meta-anorthosite is exposed over a strike length of $\sim 300 \mathrm{~m}$. About a dozen other smaller, isolated bodies of meta-anorthosite are known approximately along its strike extension over a N-S zone of $\sim 12 \mathrm{~km}$. Detailed descriptions of the petrology and geochemistry of several of these bodies have been given by Drury et al (1978), Ramakrishnan et al (1978) Naqvi and Hussain (1979), Ramakrishnan and Viswanatha (1981) Kutty et al (1984). In the Dodkadnur complex, meta-anorthosite grades to metagabbro across strike. Locally, metagabbro grades to magnetite gabbro and a small band of titaniferrous magnetite. Elsewhere, $\sim 8 \mathrm{~km}$ north of this body, gradations between metagabbro, metapyroxenite and metaperidotite/dunite were noted (Kutty et al 1984). Unlike the Honnavalli rocks, the Dodkadnur outcrops show a strong N-S gneissic foliation marked by alternate plagioclase and hornblende-rich laminae and a distinct lineation due to parallelism of hornblende. This foliation, parallel to the axial planes of large isoclinal folds $\left(\mathrm{D}_{1}\right)$, is refolded by open folds associated with well-developed NNW to $\mathrm{N}$ striking axial planes. Granulation and recrystallisation of the coarse polysynthetically twinned plagioclase into aggregates of fine untwined plagioclase is ubiquitous. The recrystallised domains show granoblastic polygonal equilibrium texture. Garnet has developed in some metagabbroic anorthosites and metagabbros. Typically the garnets are euhedral, up to $1 \mathrm{~cm}$ across, and show faces truncating foliation. Some contain abundant inclusions of fine aggregates of plagioclase and hornblende. The textures suggest that garnet growth outlasted $\mathrm{D}_{2}$-deformation. Accessories include sphene and traces of apatite besides others noted for the Honnavalli rocks.

The available major and trace element compositions (data from Drury et al 1978; Naqvi and Hussain 1979; Hussain and Ahmad 1982; Kutty et al 1984 and our unpublished results) indicate that the Dodkadnur and Honnavalli meta-anorthosite suites are geochemically similar among themselves and to many other anorthosite complexes of the Archean greenstone belts (e.g., Henderson et al 1976; Phinney et al 1988; Ashwal 1993). The most significant feature of the present set of rocks is their extremely low abundance of $\mathrm{K}, \mathrm{Rb}, \mathrm{Sr}$, $\mathrm{Y}$ and REE, even in the garnet-bearing samples. This is consistent with their mineral composition which is devoid of light rare earth element (LREE)-rich accessory phases like zircon, allanite, and monazite. The meta-anorthosites and gabbroic anorthosites show a marginal enrichment of LREE in their chondritenormalised REE pattterns $\left(\mathrm{Ce}_{\mathrm{N}} / \mathrm{Yb}_{\mathrm{N}}=1-2.6\right)$, low REE (4-9 $\times$ chondrite) and variable positive Euanomalies $\left(\mathrm{Eu} / \mathrm{Eu}^{*}\right.$ between 1.8 and 7.2). Kutty et al (1984) described that the compositional variations within the Dodkadnur complex resulted from lowpressure fractionation of a tholeiitic magma. They suggested distinct fractionation trends controlled by separation of olivine, clinopyroxene, plagioclase and magnetite. Hussain and Ahmad (1982) also suggested a similar magmatic evolution for the Honnavalli suite. The samples analysed here are limited mostly to a narrow compositional window where fractionation of clinopyroxene and plagioclase is important.

\section{Sm-Nd geochronology}

\subsection{Experimental techniques}

$3-5 \mathrm{~kg}$ samples were collected from fresh outcrops within an area of $\sim 30 \times 20 \mathrm{~m}$ (Honnavalli) and $\sim 200 \times 70 \mathrm{~m}$ (Dodkadnur). Fresh interior fragments or slabs $\sim 1.5-2.5 \mathrm{~cm}$ thick, $6 \times 5 \mathrm{~cm}$ on a face, were prepared along foliation. In the case of samples, YBL$19,20 \mathrm{~B}$ and $21 \mathrm{~A}$, blocks of $\sim 5 \mathrm{~kg}$ each was processed. All samples were powdered to $\sim 200$ mesh using a steel jaw crusher and a ring mill.

$\mathrm{Sm}-\mathrm{Nd}$ isotopic analysis of the Dodkadnur samples was carried out at the NGRI, Hyderabad while that of the Honnavalli samples at the IPGG, St. Petersburg. Analytical procedures were broadly similar and involved dissolution of $\sim 100 \mathrm{mg}$ powders in $\mathrm{HF}+$ $\mathrm{HNO}_{3}$ in screw capped teflon (Savilex) vials. Clear solutions were split for isotope dilution (ID) and isotopic composition (IC) measurements. Chromatographic separations of $\mathrm{Nd}$ and $\mathrm{Sm}$ followed procedures described by Richard et al (1976) with minor modifications. Isotopic compositions were measured on 
Table 1. Sm-Nd isotopic data for Holenarsipur meta-anorthosite complexes.

\begin{tabular}{|c|c|c|c|c|c|c|}
\hline Sample (rock type) & $\underset{(\mathrm{ppm})}{\mathrm{Sm}}$ & $\begin{array}{c}\mathrm{Nd} \\
(\mathrm{ppm})\end{array}$ & $\begin{array}{c}{ }^{147} \mathrm{Sm} /{ }^{144} \mathrm{Nd}^{\mathrm{a}} \\
\quad \text { (atomic) }\end{array}$ & $\begin{array}{c}{ }^{143} \mathrm{Nd} /{ }^{144} \mathrm{Nd}^{\mathrm{b}} \\
\text { (atomic) }\end{array}$ & $\begin{array}{c}\mathrm{T}_{\mathrm{CHUR}}^{\mathrm{c}} \\
(\mathrm{Ga})\end{array}$ & $\begin{array}{l}\mathrm{T}_{\mathrm{DM}}^{\mathrm{d}} \\
(\mathrm{Ga})\end{array}$ \\
\hline \multicolumn{7}{|l|}{ Honnavalli } \\
\hline O8-19 (LA) & 0.64 & 2.30 & 0.1381 & $0.51143 \pm 5$ & 3.12 & 3.32 \\
\hline YBL-20B (LA) & 0.61 & 2.27 & 0.1449 & $0.51155 \pm 5$ & 3.18 & 3.42 \\
\hline O8-19-4 (MA) & 1.06 & 4.22 & 0.1518 & $0.51171 \pm 5$ & 3.13 & 3.38 \\
\hline O8-19-3 (S) & 0.90 & 3.28 & 0.1651 & $0.51202 \pm 5$ & 2.95 & 3.31 \\
\hline YBL-21A (H) & 2.10 & 7.46 & 0.1707 & $0.51204 \pm 5$ & 3.40 & 3.69 \\
\hline O8-19-2 (H) & 1.60 & 5.27 & 0.1839 & $0.51239 \pm 5$ & - & - \\
\hline YBL-19 (H) & 1.63 & 5.44 & 0.1880 & $0.51254 \pm 5$ & - & - \\
\hline \multicolumn{7}{|l|}{ Dodkadnur } \\
\hline M-11 (MA) & 0.535 & 2.432 & 0.1318 & $0.511447 \pm 15$ & 2.78 & 3.11 \\
\hline M-3-2 (Gt.A) & 0.418 & 1.708 & 0.1478 & $0.511729 \pm 15$ & 2.82 & 3.26 \\
\hline M-18 (LA) & 0.420 & 1.706 & 0.1486 & $0.511716 \pm 15$ & 2.90 & 3.33 \\
\hline $\mathrm{M}-13(\mathrm{~S})$ & 0.250 & 0.785 & 0.1922 & $0.512431 \pm 15$ & - & - \\
\hline $\mathrm{M}-4(\mathrm{H})$ & 3.231 & 8.907 & 0.2187 & $0.512886 \pm 15$ & - & - \\
\hline
\end{tabular}

$\mathbf{L A}=$ leucocratic meta-anorthosite, $\mathbf{M A}=$ mesocratic meta-anorthosite (gabbroic anorthosite), $\mathbf{S}=$ Serpentinite (metaperdotite/pyroxene), $\mathbf{H}=$ Hornblendite (pyroxenite-gabbro), Gt. $\mathbf{A}=$ garnet bearing leucocratic meta-anorthosite.

Errors are 2 sigma of mean. ${ }^{\text {a }}$ Error in ${ }^{147} \mathrm{Sm} /{ }^{144} \mathrm{Nd}$ ratios is $0.15 \%$ for Dodkadnur samples and $0.5 \%$ for Honnavalli samples. ${ }^{\mathrm{b}}$ normalised to ${ }^{146} \mathrm{Nd} /{ }^{144} \mathrm{Nd}=0.7219 .{ }^{\mathrm{c}} \mathrm{CHUR}$ model ages calculated using: $\left({ }^{143} \mathrm{Nd} /{ }^{144} \mathrm{Nd}\right)_{\mathrm{CHUR}} 0.512638 ;\left({ }^{147} \mathrm{Sm} /{ }^{144} \mathrm{Nd}\right)_{\mathrm{CHUR}}=$ $0.1967 ;{ }^{d} \mathrm{~T}_{\mathrm{DM}}$ calculated using the equation of DePaolo $(1981)$ for samples with ${ }^{147} \mathrm{Sm} /{ }^{144} \mathrm{Nd}<0.17$.

metal-ion species using the automated, multicollector thermal ionization mass spectrometers, VG 354 at the NGRI and Finnigan MAT 261 at the IPGG, as described in detail elsewhere (Anil Kumar et al 1996 and Kotov et al 1995). ${ }^{143} \mathrm{Nd} /{ }^{144} \mathrm{Nd}$ ratios were normalized to ${ }^{146} \mathrm{Nd} /{ }^{144} \mathrm{Nd}=0.7219$ and weighted mean of ${ }^{143} \mathrm{Nd} /{ }^{144} \mathrm{Nd}$ for a La Jolla $\mathrm{Nd}$ standard were $0.511861 \pm 14(2 \sigma)$ at the NGRI (13 measurements) and $0.511845 \pm 4(2 \sigma)$ at the IPGG (31 measurements). Ages were calculated using the two-error regression method of Williamson (1968) in a computer program after Provost (1990). $\varepsilon_{\mathrm{ND}}$ were calculated by the method of Fletcher and Rossman (1982). All errors on age and initial $\mathrm{Nd}$ isotopic compositions $\left(\mathrm{Nd}_{i}\right)$ reported in this article are quoted at $2 \sigma$.

\subsection{Results}

Sm-Nd data for the two meta-anorthosite complexes are given in table 1 and plotted in figures 2(a) and 2(b). The samples from both the Honnavalli and Dodkadnur suites show a good mutual spread in their ${ }^{147} \mathrm{Sm} /{ }^{144} \mathrm{Nd}$ ratios-from 0.1381 to 0.1880 in the former and from 0.1318 to 0.2187 in the latter. Both sets define very good linear arrays as evident from MSWDs of 0.53 and 0.78 , respectively. If these straight lines are interpreted as isochrons (see next section), they give distinct ages and initial $\mathrm{Nd}$ ratios for the two suites: $3.285 \pm 0.170 \mathrm{Ga}, \varepsilon_{\mathrm{Nd}}=0.82 \pm 0.78$ for the Honnavalli rocks and $2.493 \pm 0.033 \mathrm{Ga}, \varepsilon_{\mathrm{Nd}}=$ $-2.2 \pm 0.03$ for the Dodkadnur rocks. However, $\mathrm{T}_{\mathrm{DM}}$ model ages (DePaolo 1981) for rocks with ${ }^{147} \mathrm{Sm} /$ ${ }^{144} \mathrm{Nd}<0.15$ from either suite are quite consistent (3.11 to $3.42 \mathrm{Ga}$ ) with their mean being indistinguishable from the older isochron age of $\sim 3.3 \mathrm{Ga}$.

\section{Discussion}

Three important lines of evidence show that the linear arrays (figures 2(a) and 2(b)) are indeed isochrons and not mere mixing lines without time significance. Firstly, the data in either case do not show a linear correlation between ${ }^{143} \mathrm{Nd} /{ }^{144} \mathrm{Nd}$ and $1 / \mathrm{Nd}$ that would be expected for a mixture of just two arbitrary components (Faure 1986). Secondly, as argued by previous workers, e.g., Kutty et al (1984), petrological and geochemical data indicate that the meta-anorthosite suites formed by crystal-melt fractionation processes from a homogeneous parent magma of tholeiitic composition. The observed differentiation trends are consistent with early segregation of olivine + pyroxene, closely followed by plagioclase and a middle stage precipitation of magnetite. Finally, the $\mathrm{T}_{\mathrm{DM}}$ model ages of the rock samples are concordant not only among themselves but also with the older isochron age of $3.3 \mathrm{Ga}$. This would not be the case if these samples were mixtures of two genetically unrelated components.

So, the two isochrons indicate that the Honnavalli samples evolved as closed systems for $\sim 3.3 \mathrm{Ga}$ from a common initial Nd ratio of $\varepsilon_{\mathrm{Nd}}=0.82 \pm 0.78$, whereas the Dodkadnur rocks evolved for $\sim 2.5 \mathrm{Ga}$ from a common initial ratio of $-2.2 \pm 0.03$. But the good agreement of the $\mathrm{T}_{\mathrm{DM}}$ model ages between the two compositionally similar suites together with the older Sm-Nd isochron age of $\sim 3.3 \mathrm{Ga}$ argues that both crystallized from a homogeneous parental magma close to $3.3 \mathrm{Ga}$ ago. The two complexes may be either isolated intrusions of compositionally very similar parental melts or segments of a large tectonically dismembered stratiform complex. 

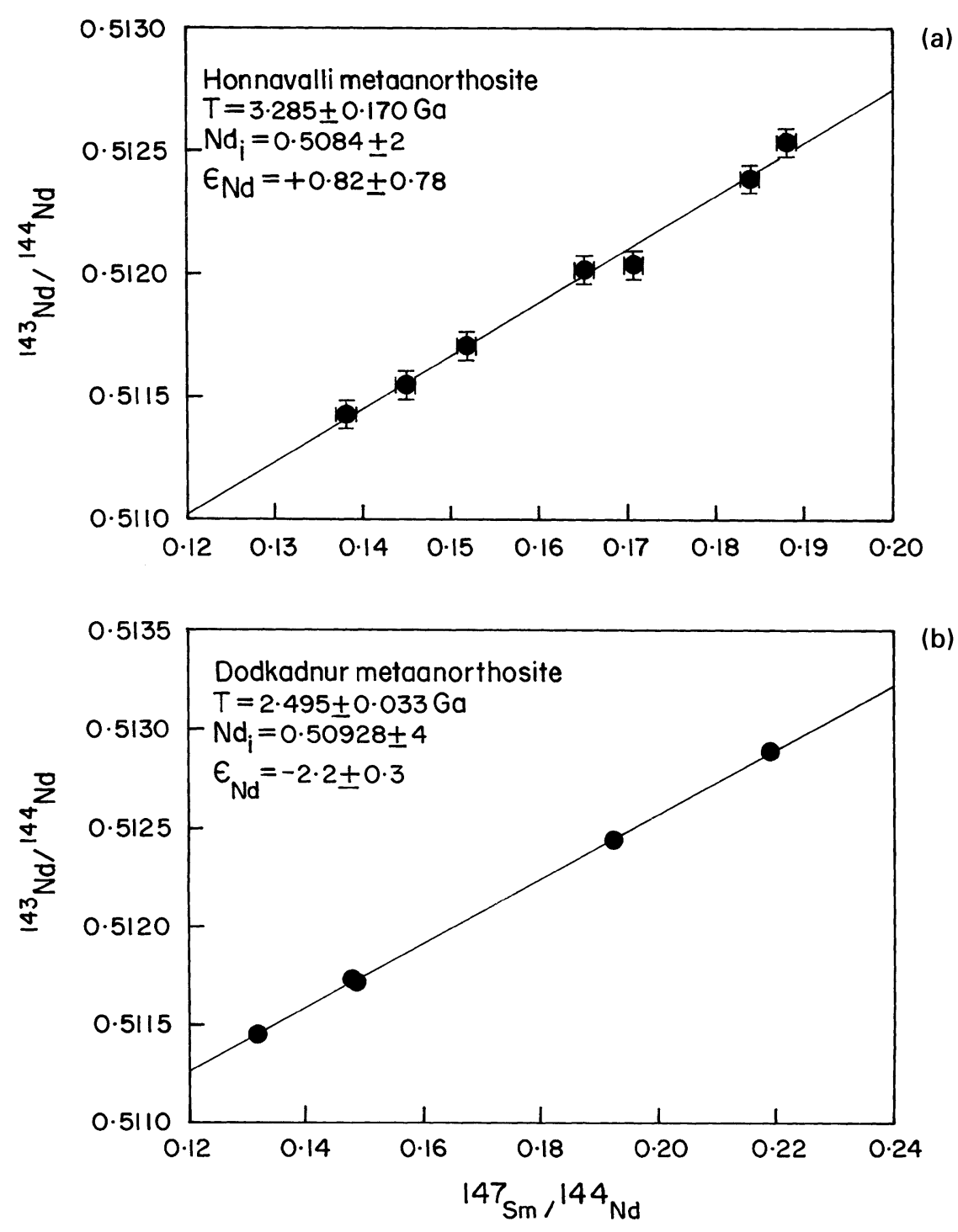

(b)

Figure 2. Sm-Nd whole rock isochron diagrams for the Honnavalli and Dodkadnur meta-anorthosite complexes around Holenarsipur.

If the Dodkadnur complex was originally coeval with the Honnavalli complex, its whole rock Sm-Nd isochron age of $\sim 2.5 \mathrm{Ga}$ implies that the rocks of this complex were re-equilibrated in their $\mathrm{Nd}$ isotopes to a common value of $\varepsilon_{\mathrm{Nd}}=-2.2 \pm 0.03$ in a secondary event about $2.5 \mathrm{Ga}$ ago. Assuming that the mean ${ }^{147} \mathrm{Sm} /{ }^{144} \mathrm{Nd}$ ratio of the five Dodkadnur rocks itself represent that of their parental magma, the $\mathrm{Nd}$ ratio of the latter $3.3 \mathrm{Ga}$ ago can be calculated from the present day mean ${ }^{147} \mathrm{Sm} /{ }^{144} \mathrm{Nd}$ ratio of 0.1678 and its ${ }^{143} \mathrm{Nd} /{ }^{144} \mathrm{Nd}$ ratio of $0.50928 \pm 4\left(\varepsilon_{\mathrm{Nd}}=-2.2 \pm 0.3\right)$ $2.5 \mathrm{Ga}$ ago. As the calculated ratio of $0.50838 \pm 4$ $\left(\varepsilon_{\mathrm{Nd}}=0.65 \pm 0.3\right)$ is well within the errors of the initial ratio of the Honnavalli rocks, the $\mathrm{Nd}$ isotopic compositions of the sources of both suites of rocks are quite similar, if not identical. In fact a regional event leading to generation of magmatic rocks and metamorphic resetting of pre-existing rocks at $2.5 \mathrm{Ga}$ has been extensively documented (see reviews Naqvi and Rogers 1987; Friend and Nutman 1991; Peucat et al
1993). More specifically, a mica schist and an amphobolite from the southern arm of the HSB both containing garnets that developed syntectonically during the $\mathrm{D}_{2}$-event gave whole rock-garnet isochrons of essentially the same age as the Dodkadnur rocks-2.473 \pm $0.010 \mathrm{Ga}, \quad \varepsilon_{\mathrm{Nd}}=-6.1 \pm 0.5$ and $2.527 \pm 0.034 \mathrm{Ga}$, $\varepsilon_{\mathrm{Nd}}=-8.7 \pm 0.4$ (Bouhallier 1995). What is then surprising about the Dodkadnur rocks is that they were isotopically re-equilibrated not on a mineral scale (as in the case of the metapelite and amphibolite) but on a scale of a few tens of centimeters, whereas the Honnavalli rocks were not. Since the only major difference between these two complexes is in the intensity of tectonic fabric developed in them, we believe that this may be responsible for the differential response of the two complexes to the secondary or metamorphic event at $2.5 \mathrm{Ga}$. The Dodkadnur complex is located within the southern arm of the HSB, which is more intensely deformed than the western part of the region hosting the Honnavalli complex-resulting in 
the development of strong $\mathrm{D}_{2}$-penetrative planar and linear mineral fabrics (Bouhallier et al 1993, 1995). The Dodkadnur rocks also show significant syntectonic recrystallisation accompanied by growth of garnets in some rock types. Evidence of sensitivity of $\mathrm{Sm}-\mathrm{Nd}$ and $\mathrm{Rb}-\mathrm{Sr}$ systematics to the intensity of deformation and the scale of penetrative fabric development in rocks rather than the intensity of the causative metamorphic event has indeed been found from studies elsewhere on multiply deformed and metamorphosed terrains (Black 1988).

Based on Rb-Sr data of 10 whole rock samples from the Dodkadnur complex, Kutty et al (1984) proposed that this complex was emplaced $3095 \pm 58 \mathrm{Ma}$ ago. Our Sm-Nd results indicate not only a much earlier time of emplacement but also the imprint of a strong secondary thermotectonic event much later. We believe the large scatter in their Rb-Sr data could be due to open system behavior of the whole rock $\mathrm{Rb}$ and $\mathrm{Sr}$ during the $2.5 \mathrm{Ga}$ event.

The general agreement of $\mathrm{T}_{\mathrm{DM}}$ ages with the Sm-Nd isochron age precludes significant crustal contamination of the magma parental to the meta-anorthosite complexes. This is further supported by the absence of LREE enriched refractory accessory minerals, extremely low abundances of $\mathrm{K}, \mathrm{Rb}, \mathrm{Zr}, \mathrm{Y}$, and LREE, and the restricted range of contamination-sensitive $\mathrm{Rb} / \mathrm{Sr}$ and $\mathrm{La}_{\mathrm{N}} / \mathrm{Sm}_{\mathrm{N}}$ in different members of the anorthositegabbro complexes. The $\varepsilon_{\mathrm{Nd}}$ of $0.82 \pm 0.78$ therefore reflects that of the magma parental to the rocks. So their mantle source is either chondritic or marginally depleted with a maximum $\varepsilon_{\mathrm{Nd}}$ of +1.5 . This is in general agreement with the finding that other Archean stratiform complexes in greenstone-gneiss and granulitegneiss terrains were derived from mantle sources with a long term depletion in LREEs (summarised by Ashwal 1993). What is perhaps of more significance is the similarity of the mantle source $\left(\varepsilon_{\mathrm{Nd}}=1.86 \pm 0.16\right)$ for the $2.94 \mathrm{Ga}$ old Sittampundi anorthosite complex at the southern margin of the craton (Bhaskar Rao et al 1996).

The age of deposition of the supracrustal rocks in the HSB, especially its basal section, is crucial to the understanding of its relationship with the spatially associated $\sim 3.33-3.0 \mathrm{Ga}$ old orthogneisses, and to the resolution of the debate on its two-fold subdivision into an older Sargur Group and a younger Dharwar Supergroup. In the HSB, both the Sargur ( $>3 \mathrm{Ga}$ ) and Dharwar $(<2.9 \mathrm{Ga})$ rocks are believed to be in juxtaposition over a fairly large area with the former exposed only in the southern and western arms and the latter mainly in the northern arm (Ramakrishnan and Viswanatha 1981). But for the differing views on the nature of the contact (intrusive or tectonic) between the $\sim 3.0 \mathrm{Ga}$ old TTG plutons and the supracrustals in the northern part, the HSB sequence would have long been accepted as a single unbroken sequence older than $3.1 \mathrm{Ga}$. The first direct indication that the sequence could be as old as $3.3 \mathrm{Ga}$ came from magmatic zircons in metarhyolites, which gave a precise age of $3298 \pm 7 \mathrm{Ma}$. Since these zircons are interpreted as magmatic and not detrital, and the metarhyolite occurs in the upper part of the sequence close to the trondhjemite-supracrustal contact in the northern sector of the HSB, Peucat et al (1995) concluded that the entire sequence is as old, arguing that the younger Sm-Nd isochron age of $\sim 2.6 \mathrm{Ga}$ for basaltic rocks (Drury et al 1987) in the same location is ambiguous.

Although the Sm-Nd data from ultrabasic-basic rocks from the southern part of the HSB are far less coherent than for the metabasalts of the northern part, Drury et al (1987) concluded that the so-called southern 'Sargur' rocks are also not older than 3.0 Ga. The meta-anorthosite rocks we have dated now occur in the southern and western parts and at lower stratigraphic levels than the $\sim 3.3 \mathrm{Ga}$ metarhyolite in the northern part dated by Peucat et al (1995). Since the stratiform complexes are believed to be intrusives, their age of $3.285 \pm 0.170 \mathrm{Ga}$ shows that the southern part of the sequence was also deposited before $3.30 \mathrm{Ga}$ ago. Considered together with the age of $3298 \pm 7 \mathrm{Ma}$ for zircons in metarhyolite in the upper levels of the northern part, our results would further imply that the entire supracrustal succession in the HSB is a single unbroken sequence deposited not later than 3.0 Ga ago. Peucat et al (1995) have further proposed that the surrounding gneisses differ only marginally in their age relative to the supracrustal rocks and so were accreted at the same time as the accumulation of sediments in adjacent basins. But, from the presence of detrital zircons as old as $3.6 \mathrm{Ga}$ in the supracrustal rocks (Nutman et al 1992) it is equally conceivable that the protoliths of the existing or otherwise gniesses could be as old as $3.6 \mathrm{Ga}$ and their erosion provided the sediments before all of them were deformed in a region wide event.

\section{Acknowledgement}

A part of this work was carried out under the project, ILTP B-2.4 supported by the Department of Science and Technology, New Delhi and the then USSR Academy of Sciences. We thank Dr. K Gopalan for his encouragement and critial review of earlier versions of this paper. Drs. C Leelanandam and M Ramakrishnan had provided useful reviews. We thank the Director, NGRI, Hyderabad for his support and kind permission to publish this work.

\section{References}

Anil Kumar, Bhaskar Rao Y J, Sivaraman T V and Gopalan K 1996 Sm-Nd ages of Archaean metavolcanics of the Dharwar craton, South India; Precambrian Res. 80 205-216 
Ashwal L D 1993 Anorthosites, (Berlin: Springer) 422 p.

Beckinsale R D, Drury S A and Holt R W 1980 3,360 Myr old gneisses from the South Indian craton; Nature 283 469-470

Bekinsale R D, Reeves-Smith G, Gale N A, Holt R L W and Thompson B $1982 \mathrm{Rb}-\mathrm{Sr}$ and $\mathrm{Pb}-\mathrm{Pb}$ whole rock isochron ages and REE data for the Archean gneisses and granites, Karnataka State, South India; In: Indo-US workshop on the Precambrian of south India [abs.]: National Geophysical Research Institute, Hyderabad, India 35-36

Bhaskar Rao Y J, Beck W, Rama Murthy V, Nirmal Charan S and Naqvi S M 1983 Geology, geochemistry and age of metamorphism of Archean grey gneisses around Chennarayapatna, Hassan district, Karnataka, South India; In: Precambrians of South India (eds) S M Naqvi and J J W Rogers Geol. Soc. India Mem. 4 309-328

Bhaskar Rao Y J, Naha K, Srinivasan R and Gopalan K 1991 Geology, geochemistry and geochronology of the Archaean Peninsular Gneiss around Gorur, Hassan district, Karnataka, India; Proc. Indian Acad. Sci. (Earth Planet. Sci.) 100 399-412

Bhaskar Rao Y J, Chetty T R K and Janardhan A S 1996 Sm$\mathrm{Nd}$ and Rb-Sr ages and P-T history of the Archean Sittampundi and Bhavani layered meta-anorthosite complexes in Cauvery shear zone, south India: evidence for Neoproterozoic reworking of Archean crust; Contrib. Mineral Petrol. 125 237-250

Black L P 1988 Isotopic resetting of U-Pb zircon and Rb-Sr and Sm-Nd whole rock systems in Enderbyland, Antarctica: implications to the interpretation of isotopic data from polymetamorphic and multiply deformed terranes; Precambrian Res. 38 355-385

Bouhallier H, Choukroune P and Ballevre M 1993 Diaprirism, bulk homogeneous shortening, and transcurrent shearing in the Archean Dharwar craton: the Holenarsipur area, southern India; Precamb. Res. 63 43-58

Bouhallier H 1995 Evolution structurale et metamorpique de la croute continentale Archeanne (Cratone de Dharwar, Indie du sud); unpubl. Phd dissertation, Geosciences-Rennes, University of Rennes, France

Bouhallier H, Chardon D and Choukroune P 1995 Strain patterns in Archaean dome-and-basin structures: The Dharwar craton (Karnataka, South India); Earth. Planet. Sci. Lett. 135 57-75

Chadwick B, Ramakrishnan M, Viswanatha M N and Srinivasa Murthy V 1978 Structural studies in the Archean Sargur and Dharwar supracrustal rocks of the Karnataka craton; $J$. Geol. Soc. India 19 531-549

Chadwick B, Ramakrishnan M, Viswanatha M N and Srinivasa Murthy V 1981 Structural and metamorphic relations between Sargur and Dharwar supracrustal rocks and Peninsular gneisses in central Karnataka; J. Geol. Soc. India 22 557-569

Chadwick B, Vasudev V N, Krishna Rao B and Hedge G V 1992 The Dharwar Supergroup: basin development and implications for Late Archaean tectonic setting in western Karnataka, Southern India; In: The Archaean: Terrains, Processes and Metallogeny; (eds) J E Glover and S E Ho, Univ. W. Aust. Publ. 22 3-15

DePaolo D J 1981 Neodymium isotopes in the Colorado Front Range and the crust-mantle evolution in the Proterozoic; Nature 291 193-196

Drury S A, Naqvi S M and Hussain S M 1978 REE distribution in basaltic anorthosites from the Holenarsipur greenstone belt, Karnataka, South India; In: Archean Geochemistry I (eds) B F Windley and S M Naqvi, Elsevier, Amsterdam, 363-374

Drury S A, Harris N B W, Holt R N, Reeves Smith and Whitman T 1984 Precambrian tectonics and crustal evolution in South India; J. Geology 92 3-20
Drury S A, Van Calsteren P L C and Reeves-Smith G J 1987 Sm-Nd isotopic data from Archean metavolcanic rocks at Holenarsipur, South India; J. Geology 95 837-843

Faure G 1986 Principles of Isotope geology (New York: John Wiley) $589 \mathrm{p}$

Fletcher I R and Rossman K J R 1982 Precise determination of initial $\epsilon_{\mathrm{Nd}}$ from Sm-Nd isochron data; Geochim. Cosmochim. Acta. 46 1983-1987

Friend C R L and Nutman A P 1991 SHRIMP U-Pb geochronology of the Closepet granite and Peninsular gniess, Karnataka, S. India; J. Geol. Soc. India 38 357-368

Henderson P, Fishlock S J, Laul J C, Cooper T D, Conard R L, Boynton W V and Schmitt R A 1976 Rare earth element abundances in rocks and minerals from the Fiskenaesset complex, West Greenland; Earth Planet. Sci. Lett. 30 37-49

Hussain S M and Ahmad S M 1982 Anorthosite enclaves in the gneisses around Holenarsipur schist belt, Hassan district, Karnataka; J. Geol. Soc. India 26 387-391

Hussain S M and Naqvi S M 1983 Geological, geophysical and geochemical studies over the Holenarsipur schist belt, Dharwar craton, India; In: Precambrian of South India; (eds) S M Naqvi and J J W Rogers, Geol. Soc. India Mem. 4 73-95

Jackson M and Barton Jr 1996 The Messina layered intrusion, Limpopo belt, South Africa: an example of in situ contamination of an Archaean anorthosite complex by continental crust; Precambrian Res. 78 139-150

Kotov A B, Kovach V P, Sal'nikova E B, Glebovitskii V A, Yakovleva S Z, Berezhmaya N G and Myskova T A 1995 Continental crust age and formation stages in the central Aldan granulite-gneiss terrain: $\mathrm{U}-\mathrm{Pb}$ and $\mathrm{Sm}-\mathrm{Nd}$ isotopic data for granitoids; Petrology 3 87-97

Kutty T R N, Anantha Iyer G V, Ramakrishnan M and Verma S P 1984 Geochemistry of meta-anorthosites from Holenarsipur, Karnataka, south India; Lithos 17 317-328

Meen J K, Rogers J J W and Fullegar P D 1992 Lead isotopic compositions of the western Dharwar craton, southern India: Evidence for distinct Middle Archaean terranes in a Late Archean craton; Geochim. Cosmochim. Acta 56 2455-2470

Monrad J R 1983 Evolution of sialic terranes in the vicinity of the Holenarsipur belt, Hassan district, Karnataka, India; In: Precambrian of South India (eds) S M Naqvi and J J W Rogers, Geol. Soc. India Mem. 4 343-364

Naha K, Srinivasan R and Naqvi S M 1986 Structural unity in the Early Precambrian Dharwar tectonic province, Peninsular India; Quart. J. Geol. Min. Metal Soc. India 58 218-243

Naha K, Srinivasan R, Gopalan K, Pantulu G V C, Subba Rao M V, Vrevksy A B and Bogomolov Ye S 1993 The nature of the old basement in the Archean Dharwar craton of southern India and the age of the Precambrian gneiss; Proc. Indian Acad. Sci. (Earth Planet. Sci.) 102 547-565

Naqvi S M 1981 The oldest supracrustals of the Dharwar craton, India; J. Geol. Soc. India 23 458-469

Naqvi S M and Hussain S M 1979 Geochemistry of metaanorthosites from a greenstone belt in Karnataka, India; Can. J. Earth Sci. 16 1254-1264

Naqvi S M and Rogers J J W 1987 Precambrian Geology of India; (New York: Oxford University Press) 223 pp.

Nutman A P, Chadwick B, Ramakrishnan M and Viswanatha M N 1992 SHRIMP U-Pb ages of detrital zircon in Sargur supracrustal rocks in western Karnataka, southern India; $J$. Geol. Soc. India 39 367-374

Nijagunappa R 1994 Chromite mineralisation in Karnataka: a review; In: Geokarnataka - Mysore geological department centenary volume. (eds) B M Raveendra and N Renganathan, Karnataka Asst. Geologists Association, Bangalore, $148-167$

Peucat J J, Mahabaleswar B C and Jayananda M 1993 Age of younger tonalitic magmatism and granulitic metamorphism in the south Indian transition zone (Krishnagiri area); 
comparison with older Peninsular gneisses from the GorurHassan area; J. Metamorphic Geol. 11 879-888

Peucat J J, Bouhallier C, Fanning C M and Jayananda M 1995 Age of the Holenarsipur greenstone belt, relationships with the surrounding gneisses (Karnataka, South India); J. Geology 103 701-710

Phinney W C, Morrison D A and Maczuga D E 1988 Anorthosites and related megacrystic units in the evolution of Archaean crust; J. Petrology 29 1283-1323

Provost A 1990 An improved diagram for isotope data; Chem. Geol. (Isotope Geosci. Section) 80 85-89

Ramakrishnan M, Viswanatha M N, Chayapathi N and Narayanan Kutty T R 1978 Geology and geochemistry of anorthosites of Karnataka Craton and their tectonic significance; J. Geol. Soc. India 19 115-134

Ramakrishnan M, Viswanatha M N 1981 Holenarsipur belt; In: Early Precambrian supracrustals of Southern Karnataka, (eds) J Swami Nath and M Ramakrishnan, Geol. Survey India Mem. 112 115-141

Ramiengar A S, Chayapathi N, Raghunandan K R, Rao M S and Rama Rao P L 1978 Mineralogy and geochemistry of vandiferous titano-magnetite deposit and associated copper mineralisation in gabbro-anorthosites near Masanikere, Shimoga District, Karnataka, India; In: Archean Geochemistry (eds) B F Windley and S M Naqvi, (Amsterdam: Elsevier) 395-406
Richard P, Shimizu N, Allegre C J $1976{ }^{143} \mathrm{Nd} /{ }^{146} \mathrm{Nd}$, a natural tracer, an application to oceanic basalts; Earth Planet. Sci. Lett. 31 269-278

Srinivasan R 1988 Present role of the Sargur group of the Archaean Dharwar craton, south India; Indian J. Geol. 60 $57-72$

Srinivasan R and Naha K 1996 Apropos of the Sargur Group in the Early Precambrian Dhawar tectonic province, southern India. In: Recent Researches in Geology (ed) A K Saha (New Delhi: Hindustan Publishers) 16 43-46

Stroh P T, Monrad J R, Fullagar P O, Naqvi S M, Hussain S M and Rogers J J W 1983 3000-m.y.-old Halekote trondjhemite, a record of stabilisation of the Dharwar craton, In: Precambrian of South India; (eds) S M Naqvi and J J W Rogers Geol. Soc. India Mem. 4 365-376

Swami Nath J, Ramakrishnan M and Viswanatha M N 1976 Dharwar stratigraphic model and Karnataka craton evolution; Geol. Surv. India Records 107 149-175

Taylor P N, Chadwick B, Moorbath S, Ramakrishnan M and Viswanatha M N 1984 Petrography, chemistry and isotopic ages of Peninsular gneiss, Dharwar acid volcanic rocks and the Chitradurga granite with special reference to the late Archean volution of the Karnataka craton, Southern India; Precambrian Res. 23 349-375

Williamson J H 1968 Least-squares fitting of a straight line; Can. J. Phys. 46 1845-1849 